\section{B A Institute of \\ УK Business Administration \\ तर Karachi \\ Leadership and Ideas for Tomorrow}

Article 2

Volume 2 Issue 1 January - June 2007

$1-1-2007$

\title{
Front Matter of Volume 2 Number 1
}

Tufail A. Qureshi

Institute of Business Administration, Karachi, Pakistan

Follow this and additional works at: https://ir.iba.edu.pk/businessreview

Part of the Business Commons

c) (i)

This work is licensed under a Creative Commons Attribution 4.0 International License.

\section{Recommended Citation}

Qureshi, T. A. (2007). Front Matter of Volume 2 Number 1. Business Review, 2(1), 2-5. Retrieved from https://doi.org/10.54784/1990-6587.1109

This article is brought to you by iRepository for open access under the Creative Commons Attribution 4.0 License and is available at https://ir.iba.edu.pk/businessreview/vol2/iss1/2. For more information, please contact irepository@iba.edu.pk. 


\section{Volume 2 Number 1}

Business Review

January - June 2007

\section{IEA}

米

RESEARCH JOURNAL

of

THE INSTITUTE OF BUSINESS ADMINISTRATION KARACHI. 


\section{Business Review}

\section{IEA}

率

RESEARCH JOURNAL

of

THE INSTITUTE OF BUSINESS ADMINISTRATION

KARACHI. 


\title{
IEA \\ 米 \\ Business Review
}

\author{
Editorial Board \\ Danishmand \\ Director \\ Institute of Business Administration, Karachi \\ Chair
}

Tufail A. Qureshi

Editor

Advisory Board

Faisal Manzoor Arain

Khadija Malik Bari

I.A. Mukhtar

Javed Hussain

Zeenat Ismail

Mirza Sardar Hussain

Naved Ahmad

Institute of Business Administration, Karachi

\section{External Editors}

Talat A. Wazarat

Karachi University, Karachi

Akif Hassan

IQRA University, Karachi

Abdul Rashid

Institute of Business Management, Karachi

\section{Consulting Foreign Editors}

Low Sui Pheng

National University of Singapore

Singapore

S.W.S.B. Dasanayaka

University of Moratuwa

Sri Lanka

Toshio Fujita

Japan International Cooperation Agency

Tokyo, Japan
Khurshid M. Kiani

The University of West Indies

Jamaica, West Indies

Bettina Robotka

Humbolt University Berlin

Germany

Khursheed Omer

University of Houston

Downtown Texas, USA 


\section{CONTENTS}

Editorial Perspective

\section{Motif}

Japan Pakistan Economic Relations: Challenges and Opportunities from Japan's New Economy: Seiji Kojima

Japanese Ambassador Extraordinary and Plenipotentiary

\section{Articles}

On Predictability in South Asian Stock Markets: Khurshid M. Kiani

Authentic Leadership Style and its Implications in Project Management: Shamas-ur-Rehman Toor, George Ofori, Faisal Manzoor Arain

Contemporary Attempts at Overcoming Decadence and Revitalizing

Qur'anic Thought: Muhammad 'Ata al-Sid

Investigating Technicist-managerialism in the Values Endorsed in MBA Programmes: Sara Khan

The Scale of Operation, Profitability based Productivity and Capacity Utilization in Seaports, The Case Study based on the Colombo Seaport in Sri Lanka, 1980-2005: Sarath W.S.B. Dasanayaka

Financial Reforms and Common Stochastic Trends in International Stock Prices: A Case Study of Pakistan: Mohammed Nishat, Ch. Muhammad Irfan

\section{Research}

Towards a Vision 2030: Direction of Industrial Development in Pakistan A Summary of the Study conducted by: Japan International Cooperation Agency and International Development Center of Japan

\section{Discussions}

The Analysis of Non-Financial Qualitative Factors for Corporate Value Creation: Syed Umar Farooq

Corruption Improves Efficiency: An Erroneous Belief: Naved Ahmad

Innovation Studies in Different Countries: Future Research Agenda for Pakistan: Syed Awais Ahmad Tipu

The Case for including Study of Arts in Management Development Curricula: Humayun S. Ansari

Diversification in Banking Sector with Special Reference to Finance: Yaseen Ahmed Meenai

\section{Book Reviews}

Aman U. Sayed: Management Accounting for Financial Services, BUSINESS REVIEW

Jim Collins: Good to Great, Harper Business, Mohammad Ahsan Siddique 


\section{Editorial Perspective}

$\mathrm{O}$ ne of the essential characteristics of a research culture is its quest for reality. What gives it a distinguishing feature is its fidelity to truth. We, the teachers and research scholars, will not be true to our calling if we were not sentimentally attached to the enduring truth and reality. Such an attitude is an abiding attribute of a genuine research methodology. It deepens our longing for the truth and inculcates in our mind the creative discontent with what is taken for granted and believed to be the reality. Research methodology aspires for the essential knowledge. Mystics, saints and philosophers, like Imam Ghazali, define this knowledge as the "taste" i.e., the lingering affect of knowing. According to him, "he who has tasted, knows". Philosophy, ethics, virtue, wisdom, education and research aspire for the 'apodictic knowledge', i.e., the knowledge we cannot doubt or even think to be other than what it is.

Analytically, epistemology refers to the quest for such knowledge. It is based upon an indomitable courage to question the underlying assumptions of our knowledge. As this tendency develops into a cultural attitude the endemic passion reaches a point where research becomes revolution. It then becomes incumbent upon a student of research to recognize clearly and distinctly, not only the truth but also our erroneous beliefs and uncritically accepted assumptions so that we may evolve and grow beyond them. The ideal here is to arrive at the absolutely certain knowledge which is what it is simply because it cannot be other than what it is. Motivated by such a passion and inspired by the purity of the heart to will the truth, research becomes iconoclastic. It then engages in demolishing what Bacon called the idols of the mind to seek freedom from their petrifying bondage.

Seekers and lovers are by temperament patient people, willing to wait eagerly for the reality to manifest itself from behind the veil of appearance. Greeks defined philosophy as the love of wisdom and the search for truth. However, tradition notwithstanding, it is not true that we are all philosophers. But it ought to be.

These are basic methodological requirements for the beginning of serious research. All serious research is motivated by an intense desire for truth and reality, deep and profound personal humility, an all consuming passion for excellence and, above all, professional will to reach out beyond the taken for granted attitude. Philosophically, it signifies cognitive dissonance and creative rage against "thus it is and cannot be otherwise". Dogmatic and forbidding knowledge claims are, by definition, antithetical to the passionate quest of a research scholar and his unassailable desire to know: why? A research scholar, by nature, is a curious mixture of discontent with the unexamined finality of "thus it is". He is possessed by the creative will to establish the reign of "thus it ought to be". Nietzsche, an enigmatic and sadly misunderstood thinker, spoke of the "will to power", meaning the will to truth. According to him, a will that does not will the truth is a will that wills nothing; it is a hopelessly powerless will. 
To be a research scholar means to be humble and open minded, to be intelligent and to be persistently experimental and willing to believe that "over each possessor of knowledge there is one more learned" (Al-Qur'an). Such men grow by out-growing themselves; they live in order to outlive. They celebrate becoming and strive to become what they are capable of becoming. They do not fear change and they are not afraid to test their knowledge in a constantly changing environment. They are the ones destined to survive by exercising their will to creatively meet the challenges of their environment.

In his Muqadima, Ibn Khaldun firmly established the empirical truth of survival with the help of his theory of "challenge and response". Survival, according to him, is contingent upon our response-ability, i.e., our ability to creatively respond to the challenges of our circumstances and vicissitudes of life. A. J. Toynbee, in his A Study of History, attested to the hypothesis formulated by Khaldun. Darwin is known for the devastating Machiavellian application of his theory of "survival of the fittest". But he was a victim of misunderstanding by association in the field of moral and political action. A critical appreciation of Darwin's Origin of Species reveals that he was very much in sympathy with the views formulated by Toynbee and Khaldun. According to Darwin, "it is not the strongest of the species that survive, nor the most intelligent, but the most responsive to change".

But man himself cannot be understood apart from his being-in-the-world. The hyphenated relationship between man and the world is the total context which defines the sense and the meaning of human situation. What is important about man's situated existence is not what the existing relationship between man and the world is but how the existing relationship is perceived and experienced by man. The meaning of the "worldliness" of the world depends upon the way man inhabits and circumstances the world.

This general observation about man's being-in-the-world is true of all the worlds, including the corporate world. Copernican revolution changed the place of man's world in the universe. The revolution initiated by Einstein who turned the universe inside out altered the meaning of human experience and radically changed the relative significance of man's relationship to the world. Marx made Hegel stand on his head, he turned him and his dialectical idealism upside down and called it the right side up. These are illustrative examples of how man's place in his world and the place of his world in the universe changes when a paradigm is radically changed. Immanuel Kant, with his Critiques, changed the concept of human mind in relation to the world. Like Marx, he made man see not a different world but the same world differently. Such is the mystique and the magic if research and discovery.

Life and research teaches us that wisdom is not attained by sudden flights. It is not given to us as a perfect deposit. Transcendence, the movement towards the 'yet to be', and the principle of change, flux and becoming are the essential components of life, nature and dynamic culture. Their application in research, especially in the field of education, shows that life is imbued with a dynamic principle, pulsating with creative 
movement towards the "yet to be". This transcendental advance and internal movement beyond the "thus it is" towards the vision of "thus it ought to be" is the élan and the creative impulse behind all genuine research. We need to integrate this insight into our philosophy of life and education to create a dynamic and future oriented research culture. No philosophy of life, no world-view, including the corporate world view, can afford to dispense with such an essential insight without corrupting the purity of moral vision and without arresting the onward movement of the creative process. If we fail to appreciate the awful consequences of this insight we sadly deny to ourselves an understanding of the social and existential implication of the principle of transcendence. Denial and gradual loss of transcendence results in the atrophy of creative will, failure of nerves, deepening shadows of fatalism and thickening gloom of despair and hopelessness.

Corporate philosophy, when it is pursued with such a bias, can help us overcome our morbid obsessions and abnormal compulsions, more so our fixations on unexamined motivations, particularly with regard to education. Money, profit and economic motivation in education are very dubious and insidious sentiments. Education is not a commodity; it is a virtue. Good education, both as an end in itself and as a means to an end, should be grounded in the passion for truth and value. It ought to beautify the mind and ennoble the character. Such value added education is not an expense; it is an asset. We must, nevertheless, be able to put some economic evaluation on education, not in terms of money, which is a nominal value, but a value in terms of moral refinement, social responsibility, creative passion, cultural vision, transcendental outlook, religious and humanistic sentiment. These are, among others, essential components of the life of an educated man and the necessary first elements of a corporate world-view. They are also the irrevocable conditions for all theoretical achievements and practical accomplishments in a corporate society.

In The World According to Drucker, Jack Beatty has so aptly pointed out that:

"Drucker discusses economic life in terms of values, integrity, character, knowledge, vision, responsibility, self-control, social integration, teamwork, community, competence, social responsibility, the quality of life, self-fulfillment, leadership, duty, purpose, dignity, meaning - but rarely money. He defends profit, but as if it were broccoli: a distasteful obligation of managers who would rather be reading Kierkegaard."

Discussing The 7 Habits of Highly Effective People, Covey makes a compelling distinction between "character ethics" and "personality ethics" and their relative managerial effectiveness in a corporate society. Today, more and more, corporate business rests on rectitude, honour, good moral judgment, authentic self-hood and strength of character. In contrast to the Sophistic proclivities, which have always contaminated the world of business and of morals, ethical orientation implies that the man of character lives and acts as a particular universal. He embodies the Kantian imperative: "act in such a way that by your will your action becomes law universal". The ramifications of such a thought make the corporate life a "trial by existence"; its implications in a corporate society are vast and deep. 
Jim Collins describes the features of a personality oriented ethics as a function of personality structure, socio-cultural habits and attitudes, presentation of self in society and its contribution to the social, public and human relations. In his Good to Great, a book inspired by the quest for the essence of excellence, Collins offers the profile of an executive who builds enduring greatness, lives and acts according to the dictates and imperatives of character ethics. "Compared to high profile leaders with big personalities who make headlines and become celebrities, the good to great leaders seem to have come from Mars. Self-effacing, quiet, reserved, even shy - these leaders are a paradoxical blend of personal humility and professional will."

When we think about corporate world, we realize that not just the market forces but nearly all the forces, ethical, religious, moral, social, political, cultural, philosophical, economic etc., define the distinctive features of its worldliness. The plurality of its perspectival variations and their gestaltan unity implies the richest and the most diversified concept of the "world". Here, if anywhere, 'reality' has many faces and the 'truth' about it is given to us in and through our lived-experience. Because, through what else could it be given? Therefore, corporate research ought to restore and strengthen our faith in the veracity of truth and value; it should deepen and enlarge the sphere of our corporate world-view. Today, our corporate cares and concerns are becoming more and more sharply defined in terms of their relevance and consequences. They intrusively extend into the domain of research, adding to our admiration for the intrinsic greatness of human character and its pristine simplicity. They also deepen our understanding of the frailties, deadly sins and ghastly temptations of human nature. In their very compelling ways, our corporate cares and concerns pertain to:

- our morbid fear of change and denial of the process of becoming,

- the untested belief that our creative will does not make any difference in our human condition,

- the impoverished and debilitating notion that having reached a certain level of growth and development we have already become what we are capable of becoming and

- our inability to wonder if what is, is necessarily what ought to be?

Observations such as these tend to become serious research questions. Pursued with the passion of the seeker of truth, they save us from the grief of hubris and the sorrow of a life based on idolatrous assumptions and hypotheses. Research celebrates the vision and the joy of freedom from the world as it is, edifying it creatively into a world as it ought to be. 